\title{
Nuclear Conquistadors: Military Colonialism in Nuclear Test Site Selection during the Cold War
}

\author{
Robert Jacobs
}

\begin{abstract}
The history of nuclear weapon testing by the major nuclear powers during the Cold War is intimately tied to the history of military colonialism in the 20th century. For each of the first five nuclear powers (U.S., USSR, UK, France, and China) the process of selecting a site for nuclear weapon testing was driven more by the location of a small group of politically marginalized people unable to object to being exposed to dangerous levels of radioactive fallout, to the loss of their homes, and the contamination of the land and seas providing their primary food sources, than it was by scientific and military requirements. Invariably these populations were constituted of people of a different racial, ethnic or religious group than that of the colonial power. This article examines the selection of nuclear test sites for each of the five major nuclear powers both in the reaches of their military empires and their own domestic landmasses.
\end{abstract}

Keywords nuclear testing, colonialism, nuclear weapons, radiation, radioactive fallout, subaltern

\section{Introduction: Bikini Atoll}

After the nuclear attacks on Hiroshima and Nagasaki in August 1945, the United States found itself in possession of a radical new technology with very little idea of its wartime utility. Teams of scientists had been prepared to enter Hiroshima and Nagasaki even before the nuclear attacks to conduct assessments of the weapon's effects. Hiroshima and Nagasaki were two of eight Japanese cities on a short list of targets that were not attacked with firebombs or conventional weapons to facilitate these assessments on targets that suffered no previous wartime destruction. The United States decided that ongoing tests of the new weapon were necessary to truly understand and strategize its potential (Rhodes 1986).

In the autumn of 1945 the U.S. search for a test site began. "We just took out 
dozens of maps and started looking for remote sites," recalls Horacio Rivera, one of the members of the newly formed Naval Office of Special Weapons (Weisgall 1994, 32). "Above all, it had to be away from population centers of US...and yet in an area controlled by the US," testified officials to Congress (Dibblin 1988, 20). In January of 1946 the U.S. Navy announced that Bikini Atoll in the Marshall Islands, a site that "may accurately be described as one of the most remote places of the earth," was its choice (Office of the Historian 1946, 12). Privately however, Admiral William Blandy, who would oversee the tests, explained that "[I]t was important that the local population be small and co-operative so that they could be moved to a new location with a minimum of trouble" (Weisgall 1994, 31).

On February 10, 1946, Commodore Ben H. Wyatt, the newly appointed military governor of the Marshall Islands, traveled to Bikini to inform the Bikinians of this decision. It was, of course, described as their "choice" but it was clear that the choice must align with the dictates of the new military occupiers of the islands. The Marshallese were very religious Christians, having been a frequent target of colonial missionaries. Wyatt waited until the 167 Bikinians were leaving Sunday morning church services and called them to assemble so that he could address them. U.S. military cameras began to roll. According to an official U.S. Navy account, Wyatt "compared the Bikinians to the children of Israel whom the Lord saved from their enemy and led unto the Promised Land. He told them of the bomb that men in America had made and the destruction it had wrought upon the enemy" (Richard 1957, 510). Wyatt explained that the United States was now intent on testing this new weapon so that they could "put an end to war," and that Bikini Atoll was the very best place in the world to test this weapon. He addressed King Judah, the leader of the Bikinians, and asked him if he would agree to the Bikinians leaving their home "temporarily" so that the United States could test this weapon "for the good of mankind and to end all world wars" (Niedenthal 2001, 2).

King Judah consulted with his people and replied: "If the United States government and the scientists of the world want to use our island and atoll for furthering development, which with God's blessing will result in kindness and benefit to all mankind, my people will be pleased to go elsewhere" (Kiste 1974, 28). This statement was translated in abbreviated fashion for the commodore and the cameras. This encounter was acted out eight times so that the cameras could record an adequate version for posterity. It was then put to effective use in U.S. domestic news presentations of this appropriation of Bikini. According to one military official quoted in Time magazine, "It was one hell of a good sales job" (Weisgall 1994, 114). This "sales job" had both a Marshallese, and a domestic U.S. audience, with one newsreel shown in U.S. theaters in the fall of 1946 editorializing that "The islanders are a nomadic group and are well pleased that the Yanks are going to add a little variety to their lives" (Rafferty et al. 1982, 29). In March 1946 the Bikinians were removed from their homes, never to return. 
Figure 1. Commodore Wyatt Addresses the Bikinians for U.S. Military Camera

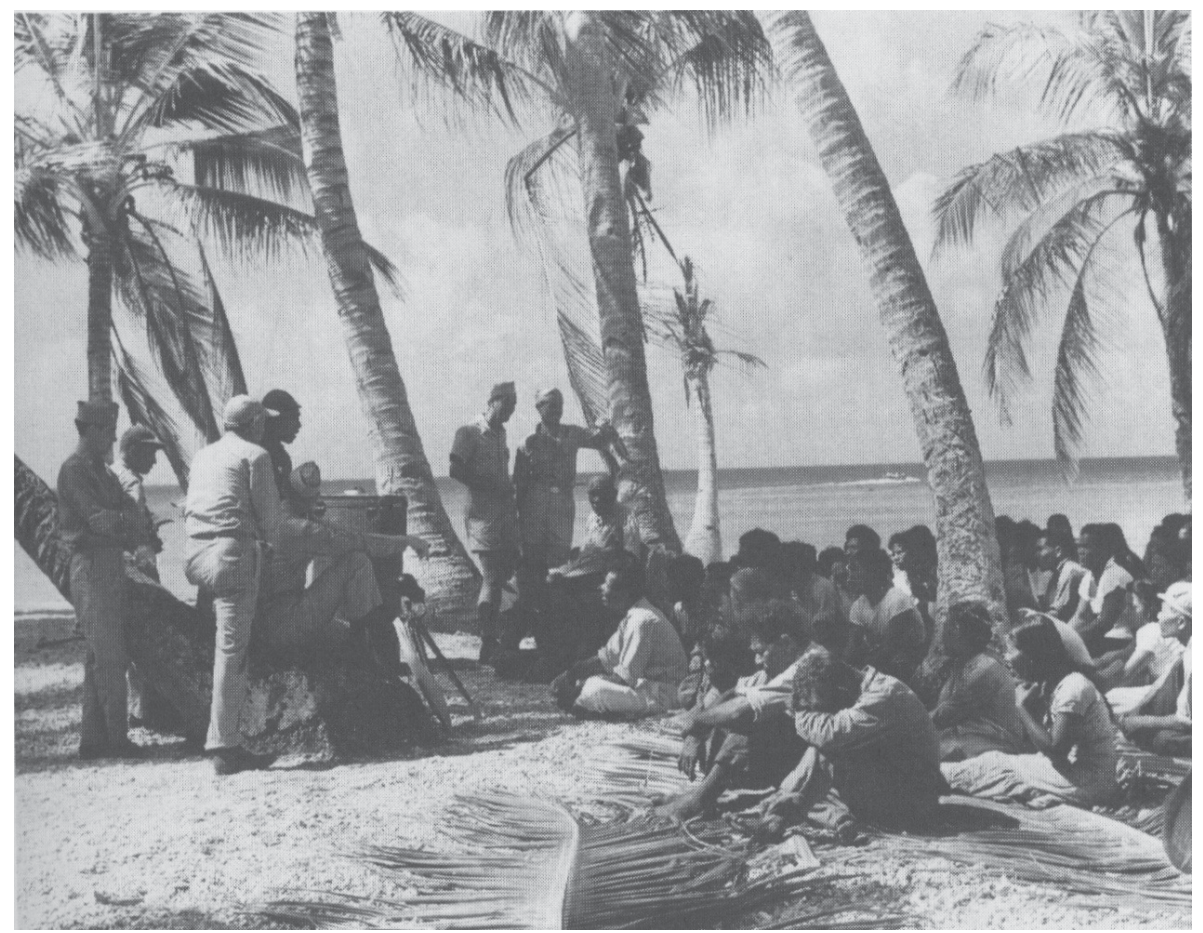

Photo by Carl Markwith @ National Geographic Society

Even after the seizure, the sense of dislocation felt by the Bikinians was utterly dismissed by Americans as they were not considered sophisticated enough to discern one atoll from another. Geographer Jeffery Sasha Davis reminds us of a contemporary 1946 New York Times Magazine article that asserted: "As for Juda and his people, now living on Rongerik Atoll, they probably will be repatriated if they insist on it, though United States military authorities can't see why they should want to: Bikini and Rongerik look as alike as two Idaho potatoes" (Davis $2005,607)$. The fact that this atoll was where their ancestors were buried, where they and their children were born, where they fell in love, where their homes were located was imagined to be of little importance to people of Bikini, for as Lt. Rooney wrote in 1946, "[p]rimitive they are” (Rooney 1946, 23).

The seizure and contamination of Bikini Atoll typifies the selection of nuclear weapon test sites around the world. Aspiring and established nuclear weapon states have selected locations for testing their nuclear arsenals that are generally located in the far reaches of their military empires or domestic landmasses, displacing and contaminating marginalized populations with little recourse, information, or compensation. Historian Gabrielle Hecht, a leading researcher on the relationship of nuclear technopolitics to colonialism, has 
written: "Once the weapons were built, the imperial cycle began anew, with atomic bombing - more palatably referred to as 'nuclear testing' - of the Marshall Islands, the Sahara, the Navajo Nation, Maralinga, Moruroa, and other colonized spaces" (Hecht 2011, 4-5). These marginal populations had no say in the use or seizure of their land, and were left to deal with displacement or with remaining in contaminated homes with contaminated food sources for generations. They have been kept in the dark about the nature of what was being done to their land or waters and about the extent of the contamination. Also, they have often had access to medical assistance denied or tightly controlled to impede them from understanding the nature or origin of their families' ongoing medical problems, and to shield information about their experiences from the world.

"Who are these radiogenic communities living adjacent to and downwind from the Cold War nuclear complex?" asks Barbara Rose Johnston. "Typically, they are the marginal and powerless groups in society: indigenous people and other social or political minorities" (Johnston 2007a, 6). However, they were not subject to the extraction of raw materials for profit by their colonial occupiers; what they possessed was open space that could be contaminated without political recourse. Their colonialism was that of a dumping ground and what was dumped there were the most toxic substances on Earth that would plague them and will plague their descendants for untold generations. Their marginality, their powerlessness, was the resource that drew their imperial occupiers to focus on their lands and their seas. In a meeting of the Advisory Committee on Biology and Medicine of the U.S. Atomic Energy Commission (AEC), in January of 1956, Merril Eisenbud, the Director of the AEC's Health and Safety Laboratory in New York, spoke about the useful information to be gleaned through the study of the Marshallese who had just been returned to their homes on Utirik Atoll after the 1954 Bravo test, a place he referred to as "by far the most contaminated place on Earth." Eisenbud made plain his view of the dignity and humanity that he afforded to the Utirikese: "While it is true that these people do not live, I would say, the way Westerners do, civilized people, it is nevertheless also true that these people are more like us than mice" (cited in Johnston 2007b, 25). Eisnebud's insinuation was that their race, their ethnicity, their religion, their class, and their lack of technological modernism made them unlike us enough that their integrity and welfare could be trivialized and ignored. Thus the nuclear subaltern was identified, marginalized, and brutalized.

Odd Arne Westad has pointed out that "the Cold War was a continuation of colonialism through slightly different means" (Westad 2007, 396). This article explores a primary example of those "different means" and extends the notion that, while scholars construct the Cold War as a conflict between two superpowers, it was against the subjects of their military empires that this power was physically exerted. 


\section{Background: Nuclear Weapon Testing}

Atmospheric nuclear weapon testing generates high levels of radioactive fallout. When the fireball of a nuclear weapon detonation touches the earth, large amounts of dust and other materials are drawn up into the mushroom cloud and are made radioactive. This dust, in addition to the byproducts of the detonation, distributes such things as plutonium and uranium-235 along with the newly ionized particles. The weight of these radionuclides leads them to fallout of the cloud subsequently contaminating areas downwind from the test site (Glasstone and Dolan 1977). The communities that live near the test site and further downwind experience significant contamination, either of land that is essential for food production as well as the location of their homes, or of the sea that provides their food. Underground nuclear testing still causes contamination close to the test site, and often "vents" radioactivity into the atmosphere, but typically in smaller quantities than atmospheric testing (Miller 1991). It is also important to understand the difference between fission weapons (A-bombs) and fusion, or thermonuclear weapons (H-bombs). From the point of view of its yield, a thermonuclear weapon is thousands of times more powerful than a fission weapon like those used in the attacks on Hiroshima and Nagasaki (Glasstone and Dolan 1977). The Bravo test in 1954 by the United States in the Marshall Islands helped military planners to understand that radioactive fallout from a thermonuclear weapon could be used as its primary effect and could contaminate the entire population of a country (Rosenberg 1983). The AEC officials superimposed the fallout map from the Bravo test onto a map of the Eastern seaboard of the United States and determined that had it been dropped on Washington, D.C., and had the winds blown in the same direction, it would have resulted in the contamination of a zone from Washington D.C. to Boston that would have to be evacuated to avoid deadly levels of radioactive exposure (Glasstone and Dolan 1977). Populations that were subjected to the testing of thermonuclear weapons were exposed to far higher levels of radiation than those affected by fission bomb testing, and experienced a much more significant long term contamination of land and water in their communities, most of which remain dangerous today, even though they are still home to thousands of people or more (Johnston and Barker 2008).

\section{The Marshall Islands for the United States}

The Marshall Islands occupy a remote section of the North Pacific relatively far from other territories. It was first colonized by the Germans in 1885, and then the Japanese during World War One (Barker 2012). The United States took control of 
the Marshalls from the Japanese in 1944 during World War II, and then after the war "a battle was fought out in the US Administration over Micronesia's political future. The War Department lobbied for outright annexation of the islands, while the State Department preferred a trusteeship system. The second option won out when in 1947 the United States and the Security Council of the United Nations signed a trusteeship agreement which brought Micronesia under the wing of the US with, theoretically, the international supervision of the UN" (Dibblin 1988, 19). While the U.S. State Department won the battle of determining the status of the Marshall Islands, the island was to become the playground of the U.S. military and AEC.

The United States began testing nuclear weapons in the Marshall Islands at Bikini Atoll, as discussed above, in 1946. Testing continued at two sites in the Marshall Islands, on Bikini and Eniwetok Atolls, until 1958. A total of 67 weapons were tested, all atmospherically including 18 thermonuclear tests (Nuclear Claims Tribunal 2006). The most devastating and perhaps illustrative of these tests was the infamous Bravo test on March 1, 1954. The Bravo test was the first test of a deliverable thermonuclear weapon by the United States. It was tested at Bikini Atoll as the first of seven tests (the Castle series) conducted within a two month period, all but one of which were thermonuclear. The Bravo test was the event that put the word "fallout" into common usage; it is almost impossible to find this term in the public literature before the Bravo test (Jacobs 2010).

The yield of the Bravo device was twice as large as weapon designers had predicted, and the United States was completely unprepared for the scale of the disaster that would follow. An immense fallout cloud moved away from the test site and blanketed a large area of the Pacific Ocean to the East of Bikini, including many populated islands and atolls. While the people of nearby Rongelap and several other atolls had been evacuated as a precaution during the 1946 tests at Bikini and returned afterwards, their islands were deliberately placed outside of the narrowly designated danger zone for the Bravo test even though it was to be the largest test ever conducted (they were not even given notice that a test would occur). American radiation monitors stationed at Rongelap were evacuated on March 2 because of the high levels of fallout. Two days later, on March 4, the U.S. military returned with a large naval vessel and informed the Rongelapese that they had an hour to gather what they could after which they would be evacuated from the atoll (Johnston and Baker 2008). By now the entire population had suffered exposure to high levels of radiation for four days. The uninformed and confused Rongelapese quickly grabbed a few cherished or valuable items and boarded the ship. As the Navy boat quickly sped away they watched as their home disappeared from view over the horizon.

Many of the Rongelapese were suffering from radiation sickness. However, they were not the only victims to emerge from under the Bravo cloud. Residents of three additional atolls were also contaminated, and then three weeks later 
further victims became apparent. A Japanese tuna trawler, the Daigo Fukuyu Maru (known in English as the Lucky Dragon) pulled into port in Japan with the entire crew suffering from radiation sickness. All were treated in hospitals and one crewmember later died. The boat had been far outside of the 50-mile danger zone prescribed by the United States, and was over 100 miles away from Bikini Atoll when they were caked with fallout ash. They had no idea what it was. It was the fact of the existence of the Lucky Dragon and the contamination of its crew that put the word fallout into common usage. The United States was unable to contain information about the nature, dangers, or extent of fallout from the Bravo test as they had been able to do for previous tests. Public health specialists found radioactive fish in markets all around the rim of the Pacific Ocean, although by then a great deal of contaminated fish had already been sold and consumed (Matashichi 2011).

The sojourn of the Rongelapese continued for decades. They lived as refugees for several years as the United States attempted to decontaminate Rongelap. In 1957, the U.S. government declared Rongelap decontaminated and clean enough for the Rongelapese to return to their homes. There were, however, some restrictions placed on the Rongelapese: admonitions that they could fish from certain parts of the atoll, but not from others; that they could grow certain crops in certain areas, but not in others; that there were parts of the atoll where they could not live and should not spend time. Eventually many of the Rongelapese began to get sick again, suffering from classic radiation associated maladies including ingestion cancers, leukemia, and immune system disorders. The Rongelapese implored the United States to evacuate them again as they feared for their safety and the well-being of their families. The United States refused and continued to assert that Rongelap was clean (Johnston and Baker 2008).

Over the next few decades the Rongelapese continued to live with radioactive contamination. Even while obeying the restrictions of fishing from one beach and not another, such restrictions were obviously not being obeyed by the fish. One of the things that the Ronelapese were told not to eat was coconut crabs, a prized delicacy and major food source that is a traditional feast item for first birthdays and wedding days. The loss of key elements of their diet contributed to the deterioration of the health of the community. Since they lived a largely subsistence lifestyle, it was impossible for the Ronelapese to ignore available food sources amidst starvation and hunger, even though they knew that there may be dangers associated with consuming these foods (Barker 2012). Finally, in 1985 the environmental group Greenpeace evacuated the Rongleapese aboard their boat the Rainbow Warrior. They were taken to other atolls in the Marshall Islands to live, again, as refugees. The Rainbow Warrior then left the Marshall Islands and headed to New Zealand where it was to sail into the waters of French Polynesia to protest and disrupt an upcoming French nuclear test at Moruroa Atoll. On July 10, 1985, it was blown up with two bombs in Auckland harbor by French 
intelligence agents, killing one crewmember (Robie 1987).

\section{Kazakhstan for the Soviet Union}

On August 20, 1945, in the shadow of the successful American nuclear attacks on Hiroshima and Nagasaki, the Special Committee (Spetskom) of the Soviet State Defense Committee met in Moscow with the mission of accelerating the slow moving wartime Soviet atomic bomb project (Cochran, Noriss and Bukharin 1995). The chairman of Spetskom was Lavrenti Beria, the universally feared chief of Stalin's secret police. Two years later as the project accelerated from lab work towards an eventual test of the weapon, Beria was put in charge of selecting a site for the final assembly and testing of the Soviet Union's first nuclear weapon. Beria chose a part of the steppe in the eastern corner of the Soviet Republic of Kazakhstan along the Irtysh River, on the edge of Siberia and near the Chinese border. Beria is said to have favored the site because it was "uninhabited," ignoring the 20,000 people living close to the test site in villages and over 100,000 living about 140 kilometers downwind in the city of Semipalatinsk (Taylor 2009). First called "Moscow 400" and then "Semipalatinsk-21" the site was renamed Kurchatov after Kazakhstan obtained independence in the 1990s (Holloway 1994, 213). From 1949 until 1989 the former Soviet Union conducted 456 nuclear tests in the Polygon (as the test site was known) including 118 in the atmosphere, among them six thermonuclear weapons (Nuclear Weapon Archive 2013).

The first test in 1949 resulted in heavy contamination of the villages to the east of the Polygon as the wind had shifted and the fallout cloud was carried directly over the villages (Werner and Purvis-Roberts 2007). During the earliest Soviet tests the nearby Kazakh villagers were often not informed about nuclear tests and were both terrified and unshielded during the explosions and subsequent deposition of fallout in their communities. Sometimes the government had required them to come out of their houses and stand in the street claiming that the most significant danger was that the shock wave of the blast could damage their houses, ignoring that the lack of any shelter from passing fallout clouds would significantly increase many people's exposures. No barriers or warning signs were erected to keep villagers from accidentally wandering into highly contaminated areas and to this day access to the site is unrestricted and high radiation areas are unmarked (Werner and Purvis-Roberts 2007).

The new Kazakh government in its application for UNESCO World Heritage status for the former test site claims: "All territory of former Semipalatinsk province suffered contamination by the products of nuclear blasts, and 1.2 million people got additional irradiation within various dosage range(s)" (UNESCO 2012, 6). The World Heritage application describes how during the 1953 first test of a thermonuclear weapon in the Polygon: "(F)orty persons were left in Karaul 
village for (the) study of radiation effects on living organism(s)" (UNESCO 2012, 5). A recent epidemiological study concluded: "In terms of actual health effects, the Kazakh and Japanese scientists noted that the rate of cancer in those living in eastern Kazakhstan, the area most exposed to radiation, remains $25-30 \%$ higher than elsewhere in the country; they also reported a higher chance of mental deficiencies in children born to parents who were exposed to radioactive fallout from testing" (Kassenova 2009).

To this day thousands of Kazakhs live in villages that remain heavily contaminated by radioactivity from the Soviet era testing. Most of these people live a simple life in which they grow most of their own food, and raise most of their own livestock for meat and dairy. The horse milk that is a staple for these Kazakh villagers comes from horses that graze on contaminated grasses, and the fish that they catch come from contaminated streams. Community leaders have pleaded with both the new Kazakh government and the Russian government for help in remediating their land, or assistance in relocating. Neither has provided any help. The Kazakh government (Kazakhstan became independent in 1991) argues that they did not test weapons in the Polygon and that Russia should clean up the site. The Russian government claims that it was the Soviet Union that contaminated the site, and they are not the Soviet Union. The Kazakh people live permanently with high levels of radiation and high levels of birth defects and radiation-induced illnesses (Bauer et al. 2005).

\section{Nevada for the United States}

The United States conducted its first nuclear test in 1945 in New Mexico, near the Manhattan Project laboratory at Los Alamos where the weapon was designed and assembled. As noted above, the United States opened its Pacific Proving Ground (PPG) test site in the Marshall Islands (at the time a U.S. trust) in 1946. Once the Soviet Union acquired nuclear weapons in 1949, the United States desired a setting for nuclear weapon tests that could include battlefield maneuvers by military personnel, and additionally, weapon designers complained that the long amount of time that it took to travel back and forth to the PPG was delaying advances in weapon design in the push to beat the Soviet Union to a functional thermonuclear weapon. Towards these goals, the United States decided in early 1950 to establish a domestic nuclear weapon testing site. Several sites were considered, guided by the criteria of being flat, desolate, and far from large population centers, but military planners quickly decided on a site about 100 kilometers north of Las Vegas, in part because of its proximity to the nuclear weapons lab in Los Alamos. The Nevada Test Site (NTS) was established by late 1950, along with Camp Mercury where troops that would participate in nuclear tests would cycle in and out. The first test at the NTS was in 1951 and testing (or 
sub-critical testing) continues there today (Titus 1986).

Originally described as being virtually uninhabited, the area downwind from the NTS was populated primarily by Native Americans and Mormons, both communities with very little political agency in the United States in 1950. A recently declassified AEC memo referred to these communities as being populated by "a low-use segment of the population" (Gallagher 1993, xxiii). The policy of the AEC, which oversaw U.S. nuclear weapon testing, was to test weapons at the NTS only when the wind was blowing to the east. Typically the wind in this area would either blow towards the east, or towards the south where Las Vegas with its sizable population was located (Miller 1991). To the east, however, were thousands of Native Americans and Mormons; thus it was the explicit policy of the AEC to test nuclear weapons in Nevada when the wind was blowing directly towards the communities of Eastern Nevada and Southern Utah. The most populated town in this area was St. George, Utah, a city of 4,500 that was frequently contaminated by passing clouds of fallout. In an AEC meeting in 1955, Chairman Lewis Stauss complained about the inconvenience of the frequent contamination by the tests of St. George "which they apparently always plaster." AEC fallout expert John Bugher advised that the problem of St. George was primarily one of "public relations," while another AEC Commissioner Willard Libby remarked glibly about the people living downwind of the NTS that "People have got to learn to live with the facts of life, and part of the facts of life are fallout" (Wasserman and Solomon 1982, 89-90).

While the people living downwind of the Nevada Test Site were considered a "low-use segment of the population," they were still Americans, and as such were higher on the colonial totem pole than were the Marshallese. The United States had an explicit policy of testing only lower yield fission weapons at the NTS, and testing all of their much higher yield thermonuclear weapons at the PPG in the Marshall Islands (Glasstone and Dolan 1977). They used this colonial prioritization to help pacify the people living downwind from the NTS in official government documents. In a 1953 AEC publication titled Assuring Public Safety in Continental Weapons Tests, the AEC claimed: "Since the larger test detonations could not be held within the United States with the requisite degree of safety, construction of firing areas and supporting facilities at the Pacific Proving Ground at Eniwetok proceeded" (USAEC 1953, 81). In a 1955 AEC publication written and distributed specifically to those living downwind of the NTS, the AEC assured them that fallout from Nevada tests was insignificant, explaining: "Please understand that in following discussion of radioactive fallout, we are not talking about high-yield A-bombs or H-bombs tested elsewhere" (USAEC 1955, 11). That elsewhere was the Marshall Islands. While the downwinders at the NTS may have been considered "low-use," they were primarily white Americans. Radioactive fallout from high-yield weapons, while more than the United States was willing to inflict on its own communities, was considered fine for the Marshallese. 


\section{Australia and the Gilbert Islands for the United Kingdom}

As participants in the Manhattan Project, and possessing shared nuclear information with the Americans (as a result of the Quebec Agreement between Roosevelt and Churchill in 1943), it was relatively easy for the British to develop their own nuclear weaponry after the end of World War II (Rhodes 1986). Determining where to test that weaponry was more complicated. The British considered the United Kingdom to be too small and populated for testing nuclear weapons, even though they did briefly consider the possibility of a site in the Scottish highlands. Along with negotiations to provide Australian raw uranium to both the U.S. and UK nuclear programs in 1952, Australian Prime Minister Robert Menzies offered the British the possibility of using Australia for nuclear weapon testing (Arnold and Smith 2006). The first test was conducted on an uninhabited island off the coast of Western Australia named Monte Bello in 1952. A year later the British tested two weapons on the Australian mainland at Emu Field that resulted in significant downwind fallout along the East coast of Australia. Finding Emu Field to be too remote, in 1953 the British requested a permanent weapon test site that afforded easier access, and in 1955 it was announced by both governments that this site had been chosen at Maralinga in South Australia, not far from Emu Field. A total of seven weapons were tested at Maralinga (Arnold and Smith 2006).

At the time of the testing, the Aboriginal people of Australia had not been granted citizenship and had virtually no political power or standing. Emu Field and Maralinga were both home to several different Aboriginal tribes, although they were considered by the Australian government and the British military to be nomadic people and the land was deemed "virtually uninhabited." Walter MacDougall was a Native Patrol Officer with the Commonwealth Department of Supply in Australia whose job was to insure that the British testing effort (and nearby rocket testing range) would not infringe on the Aboriginal communities that lived in the test site area. MacDougall and one assistant attempted to survey thousands of square kilometers of desert, an impossible task. Any recommendations that he made or cautions that he raised were crisply dismissed. In the 1985 Report of the Royal Commission that investigated exposures to military personnel and civilians from British Testing in Australia, it was stated that Richard Penney, the chief British scientist on the mission, had complained that MacDougall cared more about the "affairs of a handful of natives above those of the British Commonwealth" (McClelland 1985, 308-09). Nonetheless, MacDougall declared the desert test site to be abandoned, and testing proceeded while many people were still dwelling in the prohibited areas (Gara 2008).

Today, at the site of the original detonation of the Totem test in 1953 at Emu Field a stone marker stands to warn of the dangerous radiation present. It states 
Figure 2. The Obelisk at the Site of the Totem One Test in Australia

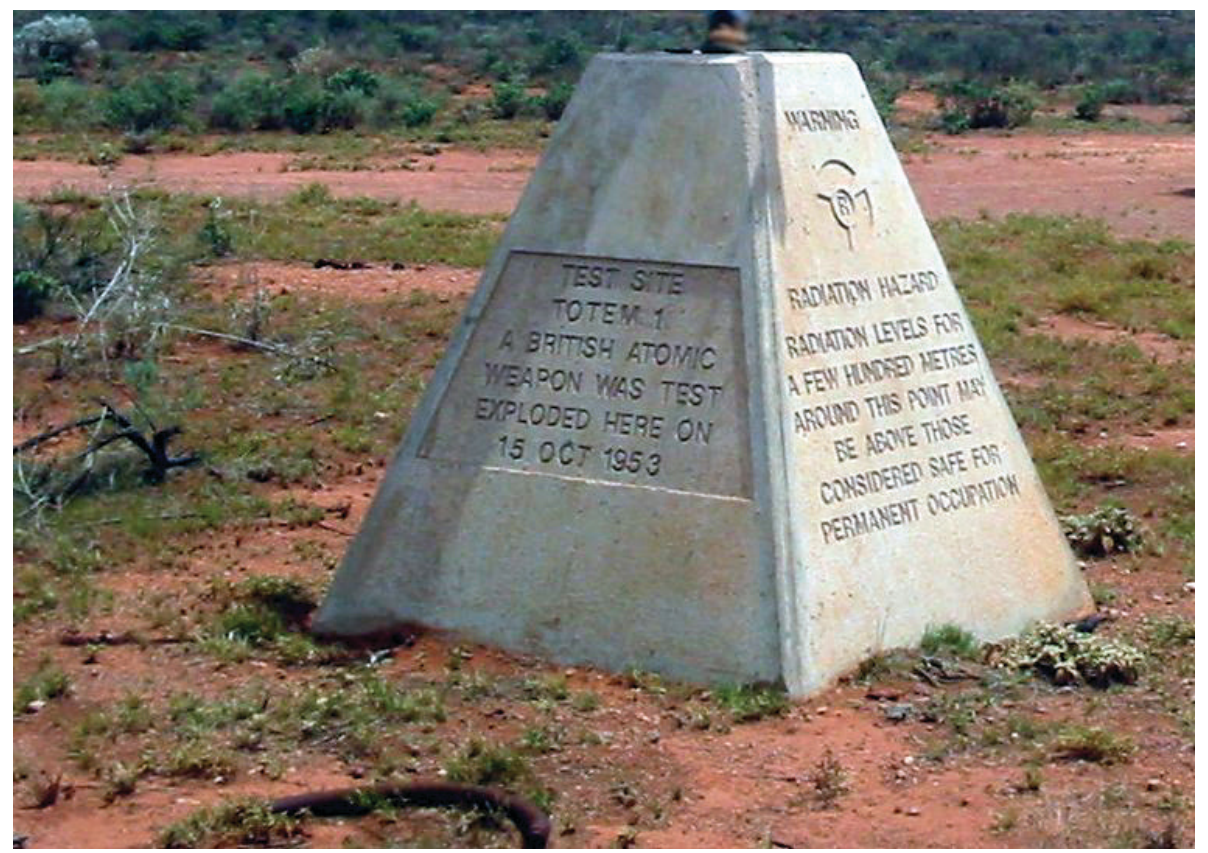

Photo by Mick Broderick

that: "Radiation Hazard: Radiation levels/ for a few hundred meters/ around this point may/ be above those/ considered safe for/ permanent occupation." Although those who traditionally occupy or live in this area are Aboriginal peoples, the marker is written in English only.

The British government had an agreement with the Australian government that it would limit the yield of weapons tested inside Australia to no more than 50 kilotons, and so when the testing of a thermonuclear weapon was being considered an alternative test site had to be established (Arnold and Smith 2006). Following the lead of the Americans, attention turned to small islands in the Pacific Ocean that were deemed far enough away from "populated" areas to allow detonation of immense weapons and their subsequent radioactive fallout (Arnold 2001). The site chosen for the first British thermonuclear test, Grapple, was Christmas Island in the Gilbert Island chain in the North Pacific.

Journalist Nic Maclellan quotes from a British military report assessing the possibilities of radiological contamination to populated areas from thermonuclear testing in the Gilberts. Imagined radiological doses are described as being culturally distinct: "For civilized populations, assumed to wear boots and clothing and to wash, the amount of exposure necessary to produce this dosage is more than is necessary to give an equivalent dosage to primitive peoples 
who are not assumed to possess these habits.... It is assumed that in the possible regions of fallout at Grapple there may be scantily clad people in boats to whom this criteria of primitive people should apply" (Maclellan 2005, 363). And at a subsequent meeting one week later in which the findings of the military report were presented to the UK defense minister, this became reduced to the simple statement: "Only very slight health hazards to people would arise, and that only to primitive peoples” (Maclellan 2005, 363).

\section{Algeria and French Polynesia for France}

As the French government was deciding to definitely pursue nuclear weapons in the late 1950s, a key problem in determining a nuclear test site was that the French empire was declining and offered limited, and often combative options for potential locations. The preferred choice of the French military was in the Sahara desert in the French colony of Algeria. However, in 1954 the Algerians began a war of independence from the French that made the investment in a large military infrastructure in the desert to stage and support nuclear weapon testing a questionable investment. Another option was French colonial holdings in the South Pacific, an area which the French had largely ignored and which lacked the infrastructure such as airfields, power generation and intact structures to house the materials and personnel to stage the tests. Also, it was on the other side of the world and would be impossible for large cargo transport planes to reach without stopping at foreign airfields en route, a scenario the French wished to avoid since the planes would be carrying sensitive and occasionally radioactive cargo (Regnault 2003).

The French did extensive studies of sites in the Alps and Pyrenees, but for underground testing, sites that would take longer to develop than those for airdropped weapons. It was also determined that there was no way to insure that radioactivity from the tests would not enter the groundwater sources for French cities (Regnault 2003, 1229-230). No such extensive studies were made of colonial sites.

In 1956 the French decided to go ahead with airdropped testing in the Southern Sahara region of Algeria, even though the war of independence made long-term use of the site doubtful. This was, however, a provisional decision. At roughly the same time it was decided to begin to develop the infrastructure, and more importantly, the political receptivity to French nuclear testing in the South Pacific (Thakur 1996). This was due to two key considerations: first, the likelihood that the French would lose access to its military bases in Algeria; and second, they did not believe that they could test thermonuclear weapons in the atmosphere in Algeria without broad opposition. Thus a site in the South Pacific was pursued even as preparations for the first French tests in Algeria were underway (Regnault 
Figure 3. Insecure Gateway at the Site of the Gerboise Bleue Test in Reganne, Algeria

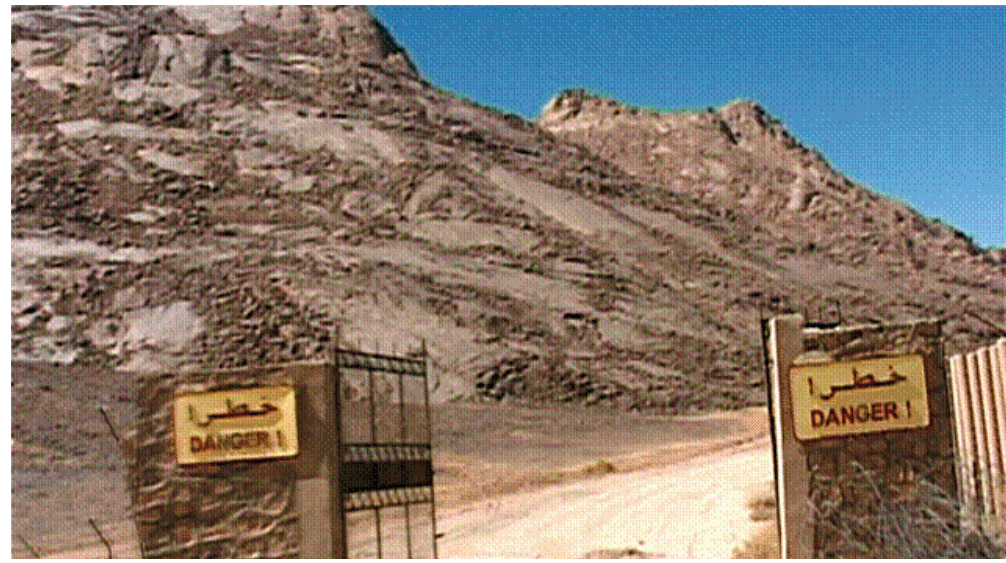

Photo still from the film, Gerboise Bleue, by Djamel Ouahab

2003).

The first French nuclear test was conducted in Algeria in 1960, an atmospheric test conducted at the test site near Reganne in Southwestern Algeria. The French conducted four atmospheric tests followed by 13 underground tests at two additional sites further to the southeast. This period of testing was noted for the absolute lack of any warning or safety precautions for the indigenous Touareg population, many of whom received significant exposures. Lax procedures also exposed military personnel and test site workers to dangerous levels of radiation, especially during the botched Beryl test in the spring of 1962. This regimen was complicated by the victory of Algeria in its war of independence from France in the summer of 1962 (Chikhi 2010). In the Treaty of Evian in which France recognized Algerian independence, France was able to negotiate a secret agreement that allowed it to continue with certain military activities at its bases in Algeria for five years after independence. It was the agreement that allowed the French to continue with underground testing until 1966 (Crapanzano 2010). When France abandoned its Sahara test site facilities, it did little to clean up the residual contamination, and even less to mark or warn the local population of the presence of dangerously radioactive areas near to their villages.

Historian Jean-Marc Regnault has written that in 1958 the French military began to pave the way for later nuclear testing in French colonial South Pacific territories (Regnault 2003). Except for the island of Tahiti, these holdings were of rather small islands and atolls scattered across the South and North Pacific. None were ideal for a nuclear test site without significant development. As French military and political leaders surveyed possible locations in their colonial holdings in the Pacific, one area, New Caledonia, was quickly removed from consideration as its proximity to Australia and New Zealand presented the 
likelihood of political opposition that could not be contained through colonial mechanisms. Regnault cites a letter sent from General Jean Thiry, head of the research commission on underground sites, to Jean Robert, the Director of Military Applications, in 1961, stating that in selecting a test site in the Pacific it was necessary to "make a choice based primarily on political considerations" (Regnault 2003, 1234).

That political choice ended up being the French test sites at Moruroa Atoll and Fangataufa Atoll in the Gambier Islands where the French conducted a total of 193 nuclear tests between 1966 and 1996. To secure the sites for nuclear testing, the French had to control local independence movements to eliminate the possibility that they would lose their Pacific site due to anti-colonial agitation after having lost their Saharan test site in a similar manner. The strongest opposition leader in French Polynesia was Pouvanaa a Oopa, whom the French promptly threw in jail on trumped up charges of inciting a riot to burn down Papeete (the capital city of Tahiti). With Pouvanaa in jail in France, local Polynesian opposition was leaderless and uncoordinated (Regnault 2003). Pouvanaa's party split into two, with John Teariki leading the Rassemblement Démocratique des Populations Tahitiennes, an independence party that held a majority of seats in the local Territorial Assembly. Although it was the seat of indigenous power, the Assembly itself held little real power. Teariki's party drafted a bill requiring a referendum on nuclear testing in French Polynesia. But the French-appointed governor rejected that move, saying that it was "meddling in defense problems" (Firth 1987, 95).

Soon after the commencement of French testing in 1966 President Charles de Gaulle visited French Polynesia intent on observing a nuclear test. The test was set for September 11, but was delayed because the wind was blowing in the wrong direction-towards the more heavily inhabited islands of French Polynesia rather than towards the east where the islands and atolls had smaller populations. Tired of waiting, de Gaulle ordered the test to proceed, resulting in a significant contamination of the populations of French Polynesia, the Cook Islands, Samoa and Fiji (Firth 1987).

The French continued testing even though they were aware that they were irradiating the populations of nearby atolls. If precautions were taken, they were enacted in ways that also communicated the subaltern nature of the population. Anthropologist Bengt Dannielsson has written: "As for the fifty inhabited atolls in the Taumotus, shelters had to be built in a great hurry on three of the easternmost ones. Each time a test was made in 1968, the hapless islanders were locked up in these shelters for a day or two and each time their homes also had to be 'decontaminated' by spraying them with sea water" (Dannielsson 1984, 338). 


\section{Lop Nur for China}

Less is known in the West about the decision and specifics of choosing Lop Nur as a nuclear weapon test site in China, and so this section is brief and partially circumstantial. All of China's 45 nuclear weapon tests took place at the Lop Nur site, including those of thermonuclear weapons.

Chinese leader Mao Zedong decided in 1955 that China should pursue nuclear weapon development, not as a means to challenge the immense arsenals of other nuclear states, but to raise China's status into the small club of nuclear weapon-holding countries (the first five of whom are the five permanent members of the United Nations Security Council), and to deter future attacks on China by the United States. At first the Chinese secured guidance and assistance from the Soviet Union, but that ended after the Sino-Soviet split in 1960 (Burr and Richelson 1997, 42). In 1959 China selected a nuclear weapon test site at Lop Nur, a dry salt lakebed in the Xinjiang Uyghur Autonomous Region, located in China's westernmost region and bearing a population of over 20 million people. The first successful test of a Chinese nuclear weapon was on October 16, 1964 in Lop Nur and was code named "596" in both protest and mockery of the month (June 1956) that the Soviets withdrew support for the Chinese nuclear program (Shen and Xia 2012, 112).

China did not have a military empire projected beyond its national borders, and so, like the Soviet Union, and as in the choice of a domestic testing site in the United States, internal politics determined where the nuclear test site would be placed. The Xinjiang region is the Chinese region furthest from the main centers of Chinese population located along the eastern coast of the country. Additionally, it is not the traditional home of the dominant ethnic groups in China, specifically the Han Chinese. The majority of the population of Xinjiang is Muslim and made up of many ethnicities, predominantly the Uyghur people. The population is a very diverse mix that reflects the history of the Silk Road trading period, and various conquerors and occupiers such as the Mongolians and Turkmen. There has been a substantial history of discrimination in China against the people of Xinjiang, and especially of the Uyghur population, that has led to frequent violent protests and clashes in Xinjiang and other parts of China. Some of the protests have included accusations of the deliberate radioactive contamination of the local population during the period of nuclear testing (Hastings 2011).

In 2008, the Chinese state news service Xinhau announced that undisclosed payments were being made to military personnel affected by radiation from nuclear weapon testing, but there was no mention of civilian victims or payments to civilians (Lague 2008). Chinese medical doctor and Xinjiang native Envor Tohti and Japanese physicist Jun Takada have recently calculated that atmospheric nuclear testing at Lop Nur may have resulted in hundreds of thousands of deaths 
in China and 1.2 million people receiving doses high enough to cause leukemia or other cancers (Merali 2009).

\section{Conclusion: The Contaminated Margins}

The French did not test nuclear weapons upwind of Paris, the Soviets did not test between Stalingrad and Moscow, and the British did not test in the Midlands. Testing happened at the extremes of empire. The populations subjected to exposure to radioactive fallout, subjected to the contamination of their landsubjected to having their bodies being the sites where the Cold War turned hot-were selected because of their subaltern status. This was the result of their race, their socioeconomic status, and their location at the peripheries of what was defined as civilization. While the Cold War was narrated as a war between economic systems and political ideologies, it was practiced as an asymmetric war between the technologically enabled and the technologically uninitiated, between the planet's wealthy and their colonized.

Within the military planning divisions of each of the nuclear powers criteria used for the selection of test sites were selected using scientific measures-small population, soil suited to testing, access to materials and troops. However, these criteria were not applied without limitation. It is no coincidence that the areas selected all ended up as remote from the land and populations of the nuclear power as possible: at the extremes of empire, or of domestic physical geography. While it was typically within the various criteria to choose areas with small populations, in each case those populations were of a different race, ethnicity, or religion than the majority populations of the nuclear power. In other words, if someone was to be exposed to radiation, it was to be the people at the margins of the society. "It was clear that colonialism remained central to the nuclear order's technological and geopolitical success," writes Gabrielle Hecht. "Even a short list of atomic test sites makes the point: Bikini Atoll, Semipalatinsk, Australian Aboriginal lands, the Sahara, French Polynesia" (Hecht 2012, ix). These choices were not made for scientific reasons-these were political choices expressing dominance and subjugation. ${ }^{1}$

During the Cold War, the world was divided into bipolar superpower blocs and the ultimate targets of nuclear weaponry were enemy nations of the nuclear power. However, the nature of developing and testing nuclear weapons necessitated some divisions within the domestic population of the nuclear state. When distant imperial property was held, the natives of those colonies became the population targeted with the residual radiation and destined to endure the contaminated lands and seas resulting from weapon testing. Within large nations, minority populations of different ethnicity or religions were targeted.

Except for the nuclear attacks on Hiroshima and Nagasaki, no direct use of 
nuclear weapons in combat has occurred. There have been, however, over 2,000 nuclear tests conducted since 1945 (Fedchenko and Hellaren 2012, 552-57). The people who live in these nuclear test site locations make up a virtual nation: victims of nuclear war rehearsals conducted with live weapons. They live in the contaminated margins of the imperial Cold War standoff. Their value to their colonial occupiers or national governments is that they could be dismissed as though their lives and health did not matter, without political consequence. As the U.S. Secretary of State, Henry Kissinger once said of the Marshallese: "There are only 90,000 people out there. Who gives a damn?" (Vine 2009, 183).

\section{Note}

1. Recent scholarship has shown that these dynamics were true for the production of nuclear materials as well as the testing of nuclear weapons. Gabrielle Hecht has written about colonialism in the mining of uranium in Africa (Hecht 2012), and Peter van Wyck has written about the legacies of uranium mining in native communities in Canada (van Wyck 2010). Several writers have examined the impact of uranium mining on the native communities in the American Southwest (Brugge and Goble 2002; Amundson 2002). Kate Brown has written about the devastations of landscape and community from the manufacture of plutonium (Brown 2013).

\section{References}

Amundson, Michael A. 2002. Yellowcake Towns: Uranium Mining Communities in the American West. Boulder: University Press of Colorado.

Arnold, Lorna. 2001. Britain and the H-Bomb. Baskingstoke: Palgrave Macmillan.

Arnold, Lorna, and Mark Smith, rev. eds. 2006. Britain, Australia, and the Bomb: The Nuclear Tests and Their Aftermaths. Baskingstoke: Palgrave Macmillan.

Barker, Holly M. 2012. Bravo for the Marshallese: Regaining Control in a Post-Nuclear, PostColonial World. Belmont: Wadsworth/Thompson.

Bauer, Susanne, Boris I. Gusev, Ludmila M. Pivina, Kazbek N. Apsalikov, and Berne Grosche. 2004. "Radiation Due to Local Fallout from Soviet Atmospheric Nuclear Weapon Testing in Kazakhstan: Solid Cancer Mortality in the Semipalatinsk Historical Cohort, 1960-1999." Radiation Research 164 (4): 409-19.

Brown, Kate. 2013. Plutopia: Nuclear Families, Atomic Cities, and the Great Soviet and American Plutonium Disasters. Oxford: Oxford University Press.

Brugge, Doug, and Rob Goble. 2002. "The History of Uranium Mining and the Navajo People." American Journal of Public Health 92 (9): 1410-419.

Burr, William, and Jeffery T. Richelson. 1997. "A Chinese Puzzle." The Bulletin of the Atomic Scientists 53 (4): 42-7.

Chikhi, Lamine. 2010. "French Nuclear Test in Algeria Leave Toxic Legacy." Reuters, March 4. http://in.reuters.com/article/2010/03/04/idINIndia-46657120100304 (accessed 
August 20, 2013).

Cochran, Thomas B., Robert S. Norris, and Oleg A. Bukharin. 1995. Making the Russian Bomb From Stalin to Yeltsin. Boulder: Westview Press.

Crapanzano, Vincent. 2010. "The Wound that Never Heals." Alif: Journal of Comparative Poetics 30: 57-84.

Dannielsson, Bengt. 1984. "Under a Cloud of Secrecy: The French Nuclear Tests in the Southeast Pacific." Ambio 13 (5-6): 336-41.

Davis, Jeffery Sasha. 2005. "Representing Place: 'Deserted Isles' and the Reproduction of Bikini Atoll.” Annals of the Association of American Geographers 95 (3): 607-25.

Dibblin, Jane. 1988. Day of Two Suns: U.S. Nuclear Testing and the Pacific Islanders. New York: New Amsterdam Books.

Fedchenko, Vitaly, and Ragnhild Ferm Hellgren. 2012. "Appendix 12B. Nuclear Explosions, 1945-2006." In SIPRI Yearbook 2012: Armaments, Disarmament and International Security. Stockholm International Peace Research Institute. Oxford: Oxford University Press.

Firth, Stewart. 1987. Nuclear Playground. Honolulu: University of Hawaii Press.

Gallagher, Carole. 1993. American Ground Zero: The Secret Nuclear War. New York: Random House.

Gara, Tom. 2008. "Walter MacDougall and the Emu and Maralinga Nuclear Tests." May 1. http://www.history.sa.gov.au/history/conference/Tom_Gara2.pdf (accessed April 5, 2013).

Glasstone, Samuel, and Philip J. Dolan. 1977. The Effects of Nuclear Weapons. 3rd ed. Washington, D.C: U.S. Government Printing Office.

Hastings, Justin V. 2011. "Charting the Course of Uyghur Unrest." The China Quarterly 208: 893-912.

Hecht, Gabrielle. 2011. "Introduction." In Entangled Geographies: Empire and Technopolitics in the Global Cold War, ed. Gabrielle Hecht. Cambridge: MIT Press, 1-12.

Hecht, Gabrielle. 2012. Being Nuclear: Africans and the Global Uranium Trade. Cambridge: MIT Press.

Holloway, David. 1994. Stalin and the Bomb: The Soviet Union and Atomic Energy 19391956. New Haven: Yale University Press.

Jacobs, Robert. 2010. The Dragon's Tail: Americans Face the Atomic Age. Amherst: University of Massachusetts Press.

Johnston, Barbara Rose. 2007a. "Half-Lives, Half-Truths and Other Radioactive Legacies of the Cold War." In Half-Lives and Half-Truths: Confronting the Radioactive Legacies of the Cold War, ed. Barbara Rose Johnston. Santa Fe: School for Advanced Research Press, 1-23.

Johnston, Barbara Rose. 2007b. “More Like Us Than Mice’: Radiation Experiments with Indigenous Peoples." In Half-Lives and Half-Truths: Confronting the Radioactive Legacies of the Cold War, ed. Barbara Rose Johnston. Santa Fe: School for Advanced Research Press, 25-54.

Johnston, Barbara Rose, and Holly M. Baker. 2008. Consequential Damages of Nuclear War: The Rongelap Report. Walnut Creek: Left Coast Press.

Kassenova, Togzhan. 2009. "The Lasting Toll of Semipalatinsk's Nuclear Testing." The Bulletin of Atomic Scientists, September 28. http://www.thebulletin.org/web-edition/ features/the-lasting-toll-of-semipalatinsks-nuclear-testing (accessed March 14, 2013). 
Kiste, Robert C. 1974. The Bikinians: A Study in Forced Migration. Menlo Park: Cummings Publishing Company.

Lague, David. 2008. "China Nows Pays Troops Involved in Nuclear Tests." The New York Times, January 28. http://www.nytimes.com/2008/01/28/world/asia/28china.html? $\mathrm{r}=0$ (accessed April 7, 2013).

Maclellan, Nic. 2005. “The Nuclear Age in the Pacific Islands." Contemporary Pacific 17 (2): 363-72.

Matashichi, Oishi. 2011. The Day the Sun Rose in the West: Bikini, the Lucky Dragon, and I. Honolulu: University of Hawaii Press.

McClelland, James Robert. 1985. The Report of the Royal Commission into British Nuclear Tests in Australia: Volume One. Canberra: Australian Government Publishing Service.

Merali, Zeeya. 2009. "Blasts from the Past." Scientific American 301: 16-20.

Miller, Richard L. 1991. Under the Cloud: The Decades of Nuclear Testing. The Woodlands: Two Sixty Press.

Neidenthal, Jack. 2001. For the Good of Mankind: A History of the People of Bikini and Their Islands. Majuro: Bravo Publishers.

Nuclear Claims Tribunal. 2006. "US Nuclear Testing Program in the Marshall Islands." http://www.nuclearclaimstribunal.com/testing.htm (accessed April 7, 2013).

Nuclear Weapon Archive. 2013. "Soviet and Russian Nuclear Weapons History." http:// nuclearweaponarchive.org/Russia/index.html (accessed March 14, 2013).

Office of the Historian, Joint Task Force One. 1946. Operation Crossroads: The Official Pictorial Record. New York: Wm. H. Wise \& Company.

Rafferty, Kevin, Jayne Loader, and Pierce Rafferty. 1982. Atomic Cafe: The Book of the Film. New York: Bantam Books.

Regnault, Jean-Marc. 2003. "France's Search for Nuclear Test Sites, 1957-1963." The Journal of Military History 67 (4): 1223-248.

Rhodes, Richard. 1986. The Making of the Atomic Bomb. New York: Simon and Schuster.

Richard, Dorothy E. 1957. United States Naval Administration of the Trust Territories of the Pacific Islands, Vol. III. Washington, D.C.: Government Printing Office.

Robie, David. 1987. Eyes of Fire: The Last Voyage of the Rainbow Warrior. Philadelphia: New Society Publishers.

Rooney, E. J. 1946. “The Strange People from Bikini: Primitive They Are, But They Love One Another and the American Visitors Who Took Their Home." New York Times, March 23, 25, 31.

Rosenberg, David. 1983. “The Origins of Overkill: Nuclear Weapons and American Strategy, 1945-1960." International Security 7 (4): 3-71.

Shen, Zhihua, and Yafeng Xia. 2012. "Between Aid and Restriction: The Soviet Union's Changing Policies on China's Nuclear Weapon Program, 1954-1960.” Asian Perspectives 36: 95-112.

Taylor, Jerome. 2009. “The World's Worst Radiation Hotspot.” The Independent, September 10. http://www.independent.co.uk/news/world/europe/the-worlds-worst-radiationhotspot-1784502.html (accessed March 14, 2013).

Thakur, Ramesh. 1996. “The Last Bang Before a Total Ban: French Nuclear Testing in the Pacific." International Journal 51 (3): 466-86.

Titus, Constandina. 1986. Bombs in the Backyard: Atomic Testing and American Politics. Reno: University of Nevada Press. 
UNESCO. 2012. International Memory of the World Register: Documents on Closure of Semipalatinsk Test Site (Kazakhstan). http://www.unesco.org/new/fileadmin/ MULTIMEDIA/HQ/CI/CI/pdf/mow/nomination_forms/kazakhstan_ semipalatinskonline.pdf (accessed 13 March, 2013).

United States Atomic Energy Commission. 1953. Assuring Public Safety in Continental Weapons Tests. Washington, D.C.: Government Printing Office.

United States Atomic Energy Commission. 1955. Atomic Tests in Nevada. Washington, D.C.: Government Printing Office.

van Wyck, Peter. 2010. The Highway of the Atom. Montreal: McGill-Queen's University Press.

Vine, David. 2009. Islands of Shame: The History of the U.S. Military Base on Diego Garcia. Princeton: Princeton University Press.

Wasserman, Harvey, and Norman Solomon. 1982. Killing Our Own: The Disaster of America's Experience with Atomic Radiation. New York: Dell Publishing.

Weisgall, Jonathan M. 1994. Operation Crossroads: The Atomic Tests at Bikini Atoll. Annapolis: Naval Institute Press.

Werner, Cynthia, and Kathleen Purvis-Roberts. 2007. "Unravelling the Secrets of the Past: Contested Versions of Nuclear Testing in the Soviet Republic of Kazakhstan." In Half Lives and Half Truths: Confronting the Radioactive Legacies of the Cold War, ed. Barbara Rose Johnston. Santa Fe: School for Advanced Research Press, 277-98.

Westad, Odd Arne. 2007. The Global Cold War. Cambridge: Cambridge University Press.

\footnotetext{
Robert Jacobs is a historian of the cultural and social aspects of nuclear technologies at the Hiroshima Peace Institute of Hiroshima City University. He is the author of The Dragon's Tail: Americans Face the Atomic Age (University of Massachusetts, 2010) which was also published in a Japanese translation by Gaifusha in Tokyo in 2013. He is the editor of Filling the Hole in the Nuclear Future: Art and Popular Culture Respond to the Bomb (Lexington, 2010), and the co-editor of Images of Rupture in Civilization Between East and West: The Iconography of Auschwitz and Hiroshima in Eastern European Arts and Media (to be published by Köln in 2014), and has published widely on nuclear history in many countries. He is the lead researcher of the Global Hibakusha Project, which examines the cultural and social aspects of radiation exposures on families and communities around the world, primarily from nuclear weapon testing, and works to link hibakusha youth via Web 2.0 technologies.
} 
